\title{
Effect of Tender Coconut Water to Prevent Anemia on Wistar Rats Induced by Lead (Plumbum)
}

\author{
Siti Thomas Zulaikhah ${ }^{1, *}$, Joko Wahyuwibowo' , Aziz Rakha D², Dede Rizky P², Ahmad Fauzi N²
}

Siti Thomas Zulaikhah",*, Joko Wahyuwibowo ${ }^{1}$, Aziz Rakha $\mathrm{D}^{2}$, Dede Rizky $\mathrm{P}^{2}$, Ahmad Fauzi N ${ }^{2}$

'Department of Public Health Sciences, Faculty of Medicine, Sultan Agung Islamic University, INDONESIA.

${ }^{2}$ Student Faculty of Medicine, Sultan Agung Islamic University (UNISSULA) Semarang, INDONESIA.

\section{Correspondence}

\section{Siti Thomas Zulaikhah}

JI. Raya Kaligawe KM. 4 Semarang Central Java INDONESIA.

Phone no: 085727299463

E-mail: sitithomas@unissula.ac.id

History

- Submission Date: 01-08-2019;

- Review completed: 29-08-2019;

- Accepted Date: 29-08-2019.

DOI : 10.5530/pj.2019.11.204

Article Available online http://www.phcogj.com/v11/i6

Copyright

(c) 2019 Phcogj.Com. This is an openaccess article distributed under the terms of the Creative Commons Attribution 4.0 International license.

\section{ABSTRACT}

Background: Tender coconut water (TCW) is a nutritious healthy drink, some content as L-arginin, iron, vitamin $\mathrm{C}$, vitamin B6, folic acid and fatty acid have roles during the process of blood formation (hematopoesis). Lead $(\mathrm{Pb})$ is one of heavy metal which can trigger the formation of Reactive Oxygen Species (ROS), causing oxidative stress and hematopoetic stem cell disorders which cause the decrease of hematocrit, hemoglobin and erythrocyte levels as the sign of anemia. Aim and Objectives: This research to investigate the effect of tender coconut water to prevent anemia on lead induced rats. Material and Methods: Experimental research by post test only control group design, using 18 white wistar strain male rats randomly divided into 3 groups. Group K1 served as control, Group K2 was fed lead (10 mg/day/rat), Group K3 was given tender coconut water $(8 \mathrm{~mL} / 200 \mathrm{gr}$ BW rats/ day) orally for four weeks. Rats' blood from ophtalmicus venous was analyzed using Hematology Analyzer to measure the hemoglobin, hematocrit, and erythrocyte levels. Data were analyzed using Anova test and Kruskal Wallis. Results:That decreased levels of hematocrit, hemoglobin and erythrocyte were show in group K2 compared with group K1. Increased levels of hematocrit, hemoglobin and erythrocyte were observed significantly in both groups K3 than K2. Conclusion: Results of the present study have administration of tender coconut water $(8 \mathrm{~mL} / 200 \mathrm{gr}$ BW rats/ day for 4 weeks) could increased of hematocrit, hemoglobin and erythrocyte levels $(p<0.05)$. The administration of tender coconut water has proven to prevent the anemia indicated by the increase of hematocrit, hemoglobin and erythrocyte levels on wistar strain male rats induced by lead.

Key words: Tender coconut water, Lead (Pb), Anemia.

\section{INTRODUCTION}

Heavy metal pollution in the environment can cause hazard on health. In Indonesia, heavy metal pollution trend to increase along with industrialization process. One of the heavy metals is lead $(\mathrm{Pb})$. Lead can cause negative effect on human's health especially on haemapoitic system. Inside the human body, lead is known to affect hematology system by disturbing heme synthesis causing anemia. Lead toxicity can cause erythrocyte destruction which shortened erythrocyte's life also known as hemolytic anemia. The destruction and shortening of erythrocyte age occurs because lead causes oxidative stress in red blood cells. ${ }^{1}$ Excess exposure will cause some side effects such as anemia, hemoglobin formation disorders, nervous disorders and renal disorders. ${ }^{2}$ Hemoglobin formation is disrupted due to the lead causes oxidative stress in the hematopoetic stem cell (HSC). ${ }^{1}$ The continuously exposed to lead HSC will damage so there will be disruption in hemoglobin synthesis and the formation of red blood cells. ${ }^{3}$ WHO cited in World Prevalence of Anaemia states that there are 1.62 billion people suffer from anemia from the total population of the world. ${ }^{4}$ In Indonesia, the anemia prevalence reached $21,7 \%$ where $18,4 \%$ men and $23,9 \%$ women. ${ }^{5}$ The anemia prevalence in Central Jave reached $57,1 \%$ in year $2013{ }^{6}$
Tender coconut water is a nutritious healthy drink that has been provided by the nature, it is a nayural isotonic drink which contains almost the same as our body's blood plasma. ${ }^{7}$ Some of the nutrients in coconut water are iron, vitamin $\mathrm{C}$, vitamin B6, folic acid and fatty acid. The nutrient contents have roles during the process of blood formation (hematopoesis). Furthermore, one of the ingredients in the coconut water which is L-argininee is known to act as antioxidant and can reduce the free radical formation and vitamin $\mathrm{C}$ can also act as antioxidant by reducing lipid peroxidase which is one of reactive oxygen species (ROS). ${ }^{8}$ The result of the study conducted by Ketaren et al. states that the average hemoglobin level tends to increase at the dose of 6 $\mathrm{mL} / \mathrm{g}$ mice body weight given tender coconut water. ${ }^{9}$ Effect coconut water cardioprotective and increase antioxidant. ${ }^{10}$ The aim of this research is to investigate the effect of tender coconut water to prevent anemia in lead induced rats.

\section{MATERIAL AND METHODS}

This study was designed as eexperiments research with Post-Test Control Group Design

\section{Ethical clearance}

This study received ethical clearance from the Bioethics Committee of Medical Research / Medical

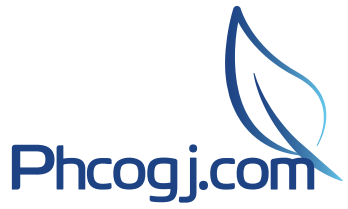

Cite this article: Zulaikhah ST, Wahyuwibowo J, Rakha AD, Rizky DP, Fauzi AN. Effect of Tender Coconut Water to Prevent Anemia on Wistar Rats Induced by Lead (Plumbum). Pharmacog J. 2019;11(6):1325-30. 
Faculty of Sultan Agung Islamic University, Semarang (51/II/2019/ Bioethics Commission).

\section{Tender coconut water}

TCW used was coconut varieties viridis (green coconut) aged 5-7 months and obtained from research surroundings. During the age 5-7 months, coconut has tender, thin, jelly like endosperm and it is edible using spoon. The dosage administered is $8 \mathrm{ml} / 200 \mathrm{grBW} /$ day for 4 weeks. ${ }^{11}$

\section{Experimental animal}

\section{Lead induction $(\mathrm{Pb})$}

The dosage of lead given is $10 \mathrm{mg} /$ day by inhalation. $10 \mathrm{mg}$ of lead powder is diluted with $1 \mathrm{~mL}$ aquadest, poured to open container, then the container is placed in the cage. This research one group consists of 6 rats, thus one cage has one $60 \mathrm{mg}$ lead container diluted with $6 \mathrm{~mL}$ aquadest. ${ }^{12}$ Male Wistar strain white rats that met the criteria which is 2 months old, weighed 180-220 g, healthy looking, active motion, normal feeding and drinking, no injuries and no disabilities. The total of 18 rats were adapted for 1 day, and then randomly werw divided into 3 groups of 6 rats each and fed the following died:

\begin{tabular}{ll}
\hline Group 1 (K1): & fed standard diet + distilled water ad libitum ) for 4 weeks \\
Group 2 (K2) $\begin{array}{l}\text { fed standard diet + distilled water ad libitum }+\mathrm{Pb} \text { inhalation (10 } \\
\mathrm{mg} \mathrm{Pb}+1 \mathrm{~mL} \text { aquadest/day) for } 4 \text { weeks } \\
\text { fed standard diet }+ \text { distilled water ad libitum }+\mathrm{Pb} \text { inhalation } \\
(10 \mathrm{mg} \mathrm{Pb}+1 \mathrm{~mL} \text { aquadest/day) }+8 \mathrm{~mL} / 200 \mathrm{~g} \text { body weight/day }\end{array}$ \\
tender coconut water for 4 weeks.
\end{tabular}

After 4 weeks, blood was drawn to measure the hemoglobin, hematocrit and erythrocyte levels.

\section{Blood drawing procedure}

The equipment used is sterile microhematrocrit tubes, blood vials, and sterile cottons. Blood is taken by inserting a microhematocrit tube in the ophthalmic vein in the corner of the rats' eyes' periorbita then slowly rotated until the blood comes out. Blood coming out is contained in ependrof as much as $2 \mathrm{cc}$. Plug out the micro hematocrit tube if the required blood is sufficient, clean the remaining blood in the corner of the rat's eye using sterile cotton. The examination of hemoglobin, hematocrit and erythrocyte using Hematology Analyzer.

\section{Research location}

The treatment of experimental animal and examination of hemoglobin, hematocrit and erythrocyte levels was carried out in PAU Gadjah Mada University Yogyakarta (Figure 1).

\section{Statistical analysis}

All statistical analyses wereperformed using SPSS softwareversion 22.0. Data were tested for normality by Shapiro-Wilk and homogeneity testing with Leuvene's Test. Data on hemoglobin and erythrocyte levels were normally distributed and homogenous so that they were analysed by parametric statistical test which is One Way Anova followed by Post Hoc LSD to determine the difference between groups. Data on hematocrit were abnormally distributed and not homogenous so they were analyze using non parametric Kruskal Wallis statistic test followed by Mann Whitney Test. ${ }^{13} \mathrm{P}$-values<.0,05were considered to be statistically significant.

\section{RESUTLS}

The effect of tender coconut water on increasing hemoglobin levels, hematocrit and erythrocyte as anemia markers is illustrated in Table 1.

Table 1 illustrated that the mean levels of hematocrit, hemoglobin and erythrocyte in group 2 decreased compared to group 1, but in group 3 , it is increased when compared to group 2 (Chart 1).

The results of analysis using Anova showed that administering tender coconut water at the dose of $8 \mathrm{~mL} / 200 \mathrm{kgBW} /$ day for 4 weeks can prevent anemia in lead induced rats marked by the increasing of hematocrit, hemoglobin and erythrocyte levels $(P<0,05)$.

\section{DISCUSSION}

Administering tender coconut water at the dose $8 \mathrm{~mL} / 200 \mathrm{gBW} /$ day for 4 weeks can prevent anemia in lead induced rats marked by increasing hematocrit, hemoglobin and erythrocyte levels $(P<0,05)$. This research proved that the mean level of blood erythrocyte on treatment group (K3) is higher compared to the mean level of blood erythrocyte in positive control group (K2). The lowest mean level of erythrocyte was found in group K2 which was only lead induced without being given tender coconut water. Lead is a heavy metal that can trigger the formation of (ROS), causing oxidative stress and hematopoetic stem cell (HSC) disorders which result in decreased hematocrit, hemoglobin and erythrocyte levels as anemic markers. ${ }^{3} \mathrm{~Pb}$

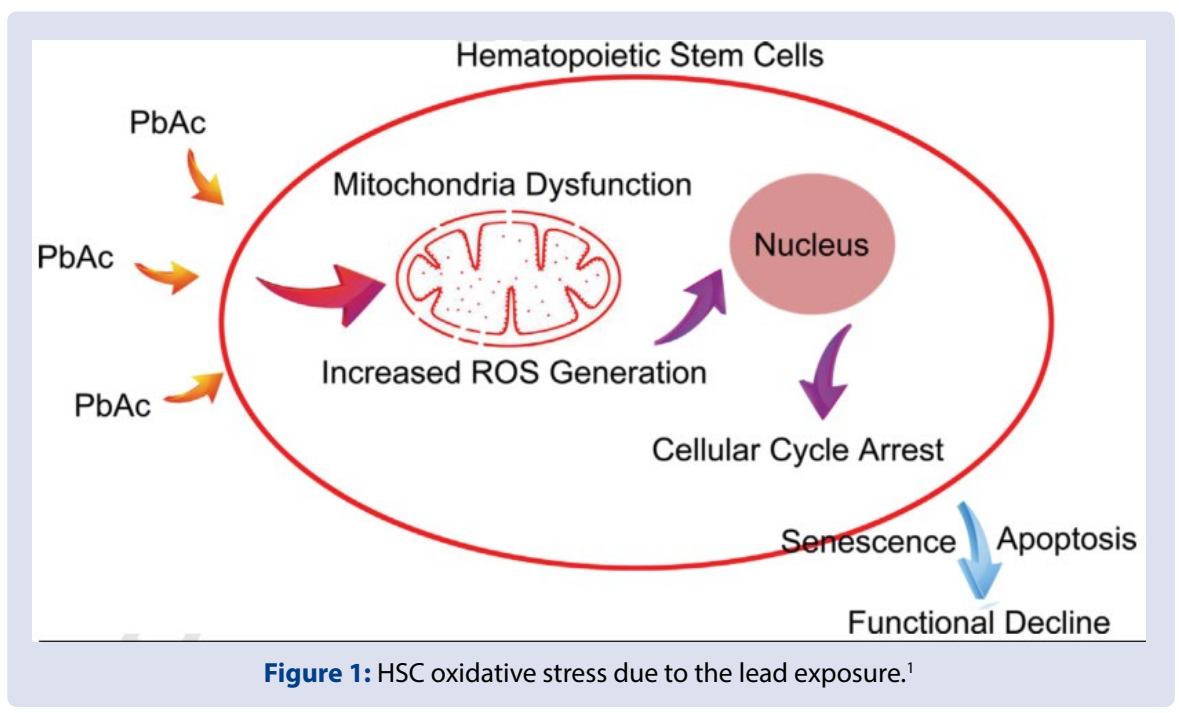


Table 1: The average of Hemoglobin (g/dL), Hematocrit (\%) dan Erythrocyte $\left(x_{10}^{3} / \mathrm{mm}^{3}\right)$ in 3 (three groups) (K1, K2, K3).

\begin{tabular}{|c|c|c|c|c|}
\hline \multirow[t]{3}{*}{ VARIABLE } & \multicolumn{4}{|c|}{ Group } \\
\hline & 1 & 2 & 3 & p-value \\
\hline & Means \pm SD & Means \pm SD & Means \pm SD & \\
\hline Hemoglobin levels(g/dL) & $15,98 \pm 0,55$ & $8,2 \pm 0,16$ & $14,94 \pm 0,76$ & \\
\hline Shapiro wilk & 0,511 & 0,930 & 0,279 & \\
\hline Levene test & & & & $>0,05^{\star}$ \\
\hline \multirow{2}{*}{ One way Anova } & & & & $0,140^{* *}$ \\
\hline & & & & $0,000^{* * *}$ \\
\hline Hematocrit Levels(\%) & $47,5 \pm 1,76$ & $24,5 \pm 0,54$ & $44,83 \pm 2,31$ & \\
\hline Shapiro wilk & 0,111 & 0,004 & 0,093 & \\
\hline Levene test & & & & $<0,05^{\star}$ \\
\hline \multirow[t]{2}{*}{ One way Anova } & & & & $0,270^{\star *}$ \\
\hline & & & & $0,001^{* * * *}$ \\
\hline Erythrocyte levels $\left(\mathrm{x}^{6} / \mathrm{mm}^{3}\right)$ & $8,64 \pm 0,23$ & $6,27 \pm 0,11$ & $7,37 \pm 0,08$ & \\
\hline Shapiro wilk & 0,493 & 0,073 & 0,331 & \\
\hline Levene test & & & & $>0,05^{*}$ \\
\hline \multirow[t]{2}{*}{ One way Anova } & & & & $0,035^{\star \star}$ \\
\hline & & & & $0,000^{* * *}$ \\
\hline
\end{tabular}

Keterangan: Signifikan ${ }^{*}>0,05$

${ }^{* *}>0,05$

$* * *<0,05$ (Anova)

$* * * *<0,05$ (Kruskall Wallis)

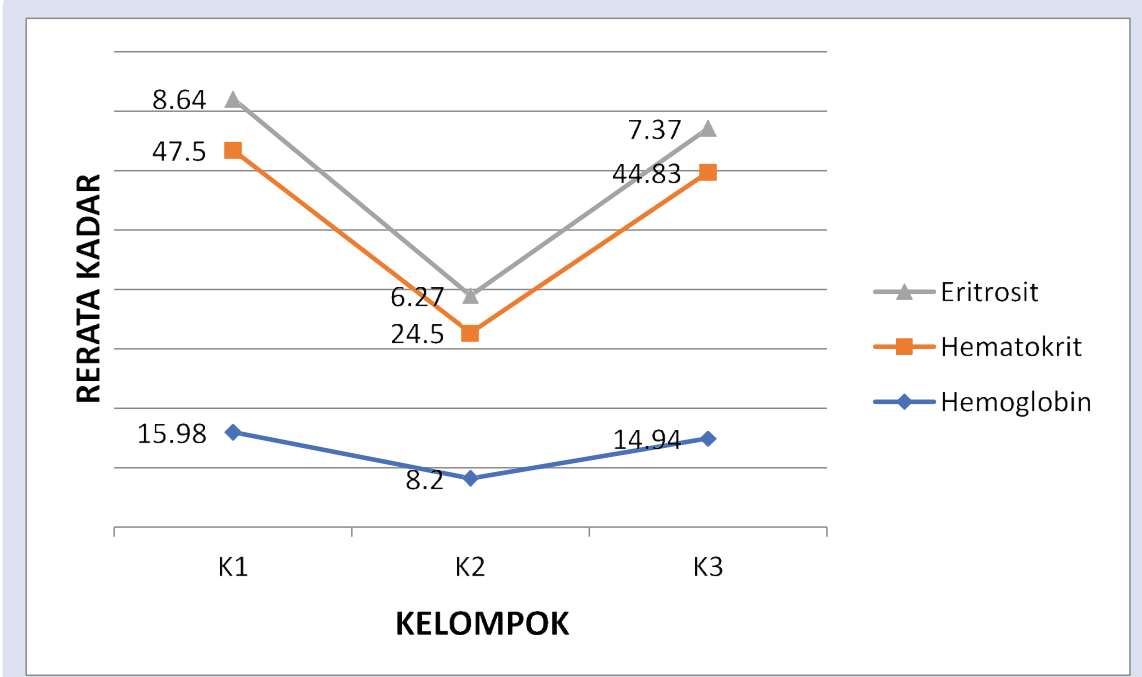

Chart 1: The average of Hemoglobin ( $\mathrm{g} / \mathrm{dL})$, Hematocrit $(\%)$ dan Erythrocyte $\left(x 10^{3} / \mathrm{mm}^{3}\right)$ in 3 (three groups) (K1, K2, K3).

exposure in the workplace was associated with anemia ${ }^{14}$, study other in children showed significant correlations between lead levels and hemoglobin $(-0.770 ; P<0.01)$, MCV $(-0.679 ; P<0.01)$, and ferritin $(-0.509 ; P<0.05) .^{15}$

Research conducted by Muliyadi et al indicated that lead levels caused haematological disorders. ${ }^{16}$ There ware association between $\mathrm{Pb}$ exposure and iron deficiency anemia in children ${ }^{17}$ and there were association between $\mathrm{Pb}$ exposure in the air and blood $\mathrm{Pb}$ levels $(\mathrm{p}=0,000 ; \mathrm{r}=0,606)$ and blood $\mathrm{Pb}$ levels and hemoglobin levels $(\mathrm{p}=0,000 ; \mathrm{r}=-0,623) .^{18}$ The decrease of blood erythrocyte levels due to the lead induction is in accordance with previous research carried out by Santosa et al. ${ }^{19}$ Erythrocyte cell damage will cause destruction of erythrocyte cells and shorthening the age of erythrocyte, while increased levels of ROS will cause damage to the DNA and mitochondria resulting in apoptosis in the erythrocyte. ${ }^{19}$ The ROS will inhibit the DNA repairing works initiated by 53 resulting in the stopping of cell cycle so that the aging will occurred in HSC or apoptosis. ${ }^{1}$
The decreased of HSC amount will result in a decrease in the number of cells from the hematopoetic systems such as leukocytes, platelets and erythrocyte. Decreasing number of erythrocyte will affects the decreased of hematocrit as well. ${ }^{1}$

Hemoglobin is free due to the erythrocyte damage will be converted to bilirubin. Thus, the clinical manifestations will be generally can be seen on patients, ranging from asymptomatic compensated with reticulocytosis with muld hyperbilirubinemia, hemoglobinuria to fulminat hemolysis with jaundice to hepatosplenomegaly. ${ }^{20}$

One of the toxicity effect of lead is the hematological system disorder and leads to anemia symptoms by disrupting the hematopoietic balance in the blood homeostasis. In the bone marrow, the erythrocyte formation process occurs in which hemoglobin involves Fe metal bound to porphyrin and globin. Fe acts as a co-factor in enzymatic formation and hemoglobin by binding to $\mathrm{O} 2$. Each hemoglobin molecule binds 4 molecules of $\mathrm{O} 2$ or 8 oxygen atoms. Because the $90 \% \mathrm{~Pb}$ is stored in the bone, the presence of $\mathrm{Pb}$ in the bone marrow will be an inhibitor in an 
enzymatic reaction by inhibiting the ALAD enzyme and ferrochelatase which play a role in the synthesis of hemoglobin. This is in accordance with research conducted by Rizkiawati which pointed that there is a relationship between blood $\mathrm{Pb}$ and blood hemoglobin levels. ${ }^{21}$ The hematopesis process is disrupted because $\mathrm{Pb}$ can cause ALAD enzyme barriers that are in the beginning of heme synthesis, coproporfirinogen oxidase enzymes and ferrochelatase enzymes which are at the end of heme biosynthesis, this disorder can cause a decrease in heme synthesis as a component of hemoglobin so it will cause anemia. The deficiency of glucose-6 phospate dehidrogenase (G-6PD) enzyme also occurs in $\mathrm{Pb}$ exposure which causes the shortening of erythrocyte age and erythrocyte maturity disturbances which results in the increase of the hematopoiesis process.

The current research is more directed at strategies to protect cells caused by free radicals. Elimination of ROS is very important to maintain the integrity of the cell function and can be done by increasing antioxidant activity. Natural antioxidants can protect the body against cell damage caused by ROS.2. Foods containing natural antioxidants can be used as a strategy to reduce morbidity and mortality especially due to the oxidative stress. ${ }^{7}$ Coconut water is a natural, healthy, nutritious drink that contains antioxidants substances such as minerals $(\mathrm{Cu}, \mathrm{Zn}, \mathrm{Mn})$, Vitamin $\mathrm{C}$, and L-argininee. ${ }^{11}$ Tender coconut water to prevent oxidative stress, reduce free radicals, increase Antioxidant Enzym, decrease lipid peroxidative. ${ }^{7,11,22-24}$

The result of this study indicate that tender coconut water at a dose of $8 \mathrm{~mL} / 200 \mathrm{gBW}$ is significantly increased hemoglobin, hematocrit and erythrocyte levels in male wistar strain rats induced by $\mathrm{Pb}$, these results are linear with previous research by Jesuorsemwen et al. that the mean hematocrit and erythrocyte levels increased in the administration of tender coconut water, ${ }^{25}$ the results of other research conducted by Safitri et al stated that the administration of tender coconut water can increase the mean of blood hemoglobin level. ${ }^{26}$ Fa'iza et al. stated that there were differences in blood Hemoglobin level before and after consumption of green coconut water in workers exposed to lead $(\mathrm{Pb})$ with $\mathrm{p}$ value $=0.001 .{ }^{27}$

The high content L-arginine in tender coconut water can be used to reduce the generation of free radicals, increase antioxidant activity and inhibit lipid peroxidation processes and have the effect of HSC damage protection because it works as an antioxidant that increases the amount and strengthens the work of the superoxide dismutase (SOD) enzyme so that the oxidation process is inhibited, this theory is supported by Talas et al. which stated that L-arginine has an effect on hematocrit levels. ${ }^{28}$ Other researchers stated that L-arginine is capable to increase the antioxidant activity in rats exposed to lead $(\mathrm{Pb}){ }^{29}$ Another antioxidant contained in tender coconut water is vitamin $\mathrm{C}$ which prevents the formation of lipid peroxidase which is a component of ROS, if the formation of ROS can be inhibited then the oxidation process in blood cells can be prevented. ${ }^{30}$ Vitamin C has role as electron donor, able to neutralize and reduce ROS so that cells are protected from damage caused by free radicals, Vitamin $\mathrm{C}$ increase iron absorption in body. ${ }^{31}$ Tender coconut water contains minerals $\mathrm{Cu}$, $\mathrm{Zn}$, dan Mn. The effectiveness of SOD enzymes can be increased by the presence of mineral nutrients such as Copper $(\mathrm{Cu})$ and $\mathrm{Zinc}(\mathrm{Zn})$ and Manganese $(\mathrm{Mn}){ }^{32}$ The high nutrients content in tender coconut water can be used as one of the important sources and minerals for the body, one of which is as a natural antioxidant cofactor SOD found found in the body. Lack of $\mathrm{Cu}, \mathrm{Zn}$ dan $\mathrm{Mn}$ minerals can reduce the $\mathrm{Cu}-\mathrm{Zn}$ SOD and Mn-SOD activities as well as causing the lipid peroxide which ends with oxidative stress. ${ }^{33} \mathrm{Mg}$ ion that makes free radicals tend to give electrons to the $\mathrm{Mg}$, thus neutralize free radicals. ${ }^{34}$ The most likely and practical way to fight against degenerative diseases is to improve the body's antioxidant status, which could be achieved by a greater consumption of vegetables. ${ }^{35}$

\section{CONCLUSION}

The administration of tender coconut water has the effect of preventing anemia which is characterized by the increased levels of hemoglobin, hematocrit and erythrocyte.

\section{ACKNOWLEDGEMENT}

This study was funded by Faculty of Medicine Universitas Islam Sultan Agung Semarang Indonesia (2018).

\section{CONFLICTS OF INTEREST}

The authors declare that they have no conflicts of interest.

\section{ABBREVIATION}

TCW: Tender Coconut Water; ROS: Reactive Oxygen Specie; $\mathbf{P b}$ : Plumbum; HSC: hematopoetic stem cell; Hb: Hemoglobin; DNA: Deoxyribo Nucleic Acid; ALAD: Aminolevulinic Acid Dehydratase; Cu: cuprum; Zn: Zing; Mn: mangan.

\section{REFERENCES}

1. Liu J, Jia D, Cai S, Li C, Zhang M, Zhang Y, et al. Mitochondria defects are involved in lead-acetate-induced adult hematopoietic stem cell decline. Toxicol Lett. 2015;3(7):1-8

2. Malaka T, Iryani M. Hubungan Kadar Timbel dalam Darah dengan Kadar Hemoglobin dan Hematokrit pada Petugas Pintu Tol Jagorawi The Correlation of Lead in Blood and Haemoglobin Concentration and Hematocrit Value of Toll Booth Workers at Jagorawi. Kesmas. J Kesehat Masy Nas. 2011;6(1):35-41.

3. Sun X, Xie YAN, Wu L, ZhuWEI, Hu J, Lu R, et al. Lead acetate reduces the ability of human umbilical cord mesenchymal stem cells to support hematopoiesis in vitro. Mol Med Rep. 2012;(6):827-32.

4. Database WHOG. Worldwide prevalence of anaemia. 2005

5. Kementerian Kesehatan Republik Indonesia. Penelitian, Pengembangan dan Riset Kesehatan Dasar. 2013.

6. Dinkes Provinsi Jawa Tengah. Profil Kesehatan Provinsi Jawa Tengah tahun 2016. Semarang; 2016.

7. Zulaikhah ST. The role of antioxidant to prevent free radicals in the body. Sains Med J Med Heal. 2017;8(1)

8. Lima EBC, Sousa CNS, Meneses LN, Ximenes NC, Júnior MAS. Cocos nucifera (L.) (Arecaceae): A phytochemical and pharmacological review. Brazilian J Med Biol Res. 2015;48(11):953-64.

9. Ketaren KS, Novianry V, Hadi DP. Uji efektivitas air kelapa muda (Cocos nucifera L.) terhadap hemoglobin pada tikus putih (Rattus norvegicus) sebagai ant anemia setelah diinduksi siklofosfamid. Skripsi Pendidikan Dokter-Fakultas Kedokteran Universitas Tanjungpura. 2016

10. Johnkennedy N, Joy D-N, Ndubueze EH, Melvina N, Richard E VO. Antioxidant and cardioprotective effect of coconut water against doxorubicin induced cardiomyopathy. J Krishna Inst Med Sci Univ. 2013;2:37-41.

11. Zulaikhah ST, Pertiwi D, Bagus SA, Nuri S, M BJE, Alfiza NS. Effect of tender coconut water on blood lipid levels in hight fat diet fed male rats. J Krishna Inst Med Sci Univ. 2017;6(2):63-8.

12. Agus $\mathrm{S}$, Chotidjah $\mathrm{B}$. Pengaruh Pemberian Timbal (Pb) Per Oral terhadap Gambaran Histopatologi Hepar. Majalah IImiah Sultan Agung. 2012;1-12.

13. Dahlan MS. Pintu Gerbang Memahami Epidemiologi, Biostatik dan Metodologi Penelitian. Jakarta: epidemiologi Indonesia, 2018.

14. Hsieh NH, Chung SH, Chen SC, Chen WY, Cheng YH, Lin YJ et al. Anemia risk in relation to lead exposure in lead-related manufacturing. BMC Public Health. 2017;17(1):1-12.

15. Zareifar S, Mazloomi S, Zahmatkeshan M, Shahriari M, Najeeb KS, Fattah F. The association between blood lead level and microcytic hypochoromic anemia in children. Int J Sch Heal. 2016;3(4)

16. Muliyadi, Mukono, H.J. \& Notopuro H. Paparan timbal udara terhadap timbal darah, hemoglobin, cystatin $\mathrm{C}$ serum pekerja pengecatan mobil. J Kesehat Masyarakat. 2015;11(1):87-95

17. Sari BT, Lubis B. Hubungan antara keracunan timbal dengan anemia defisiensi besi pada anak. Maj Kedokt Nusant. 2014;47(3):164-7.

18. Santosa B, Subagio HW, Suromo L, Sunoko HR. Zinc supplementation decreases basophilic stippling in rats exposed to lead. Universa Med. 2014;33(1):11-8.

19. Santosa B. Zinc supplementation decreases basophilic stippling in rats exposed to lead. Universa Med. 2014;33(1):11-8. 
20. Hall J. Red blood cells, anemia, and polycythemia. In Guyton and Hall textbook of medical physiology. 2016. 445-543.

21. Rizkiawati A. Faktor-Faktor Yang Berhubungan Dengan Kadar Hemoblobin ( $\mathrm{Hb})$ Dalam Darah Pada Tukang Becak Di Pasar Mranggen Demak. J Kesehat Masy. 2012;1(2):663-9.

22. Zulaikhah ST, Sampurna S. Tender coconut water to prevent oxidative stress due to mercury exposure. IOSR J Environ Sci Toxicol Food Technol. 2016;10(6):35-8.

23. Zulaikhah ST. Health benefits of tender coconut water (TCW). Int J Pharm Sc Res. 2019;10(2):474-80

24. Jesuorsemwen E Ben, Ebikere II, Ozede IN, Eghomwanre AF Hematobiochemical changes of lead Poisoning and amelioration with Coconut (Cocos nucifera L.) Water in wistar albino rats. J Appl Sci Environ Manag. 2016;20(1):89-94

25. Anagement M, Jesuorsemwen EBEN, Ebikere II, Ozede N, Frank A Hematobiochemical changes of lead Poisoning and amelioration with Coconut (Cocos nucifera L.) Water in wistar albino rats. J Appl Sci Environ Manag. 2016;20(1):89-94

26. SafitriYD, Lestari U, Wulandari N. Pengaruh air kelapa muda varietas macrocorpu terhadap kondisi hematologi mencit galur balb C. 2015.

27. Sabila Q, Setiani O, Joko T. Sebelum Dan Sesudah Konsumsi Air Kelapa Hijau (Green Coconut Water ) Pada Pekerja Yang Terpapar Timbal ( Pb ) Di Karoseri X Semarang. J Kesehat Masy. 2016;4(3):862-70.
28. Talas ZS, Gogebakan A, Orun I. Effects of propolis on blood biochemical and hematological parameters in nitric oxide synthase inhibited rats by $\mathrm{N} \omega$-NitroL-arginine methyl ester. Pak J Pharm ci. 2013;26(5):915-9.

29. Tkachenko H KN. Role of L-Arginine against lead toxicity in liver of rats with different resistance to hypoxia. Pol J Env Stud. 2011;20(5):1319-25.

30. Flora G, Gupta D, Tiwari A. Toxicity of lead: A review with recent updates. 2012;5(2):47-58.

31. Mun'im A, Meidi UP, Santi PS, Azizahwati. Anti-anemia effect of standardized extract of moringa oleifera lamk. leaves on aniline induced Rats. Pharmacognosy Journal. 2016;8(3):255-8.

32. Winarsi, H. Antioksidan Alami \& Radikal Bebas. Potensi dan aplikasinya dalam kesehatan, Yogyakarta: Kanisius.2007.

33. Zulaikhah ST, Anies, Ari S. S. Effects of Tender Coconut Water on Antioxidant Enzymatic Superoxida Dismutase ( SOD ) CATALASE ( CAT ) Glutathione Peroxidase ( GPx) and Lipid Peroxidation In Mercury Exposure Workers. Int J Sci Res. 2015;4(12):517-24.

34. Suparmi, Sampurna, Nur AC, Alvenia ME, Galuh DU, Iqrommatul L, Heavin RS Anti-anemia Effect of Chlorophyll from Katuk (Sauropus androgynus) Leaves on Female Mice Induced Sodium Nitrite. Pharmacognosy Journal. 2016;8(4):375

35. Oboh G. Prevention of garlic-induced hemolytic anemia using some tropical green leafy vegetables. J Med Food. 2004;7(4):498-501.

\section{GRAPHICAL ABSTRACT}

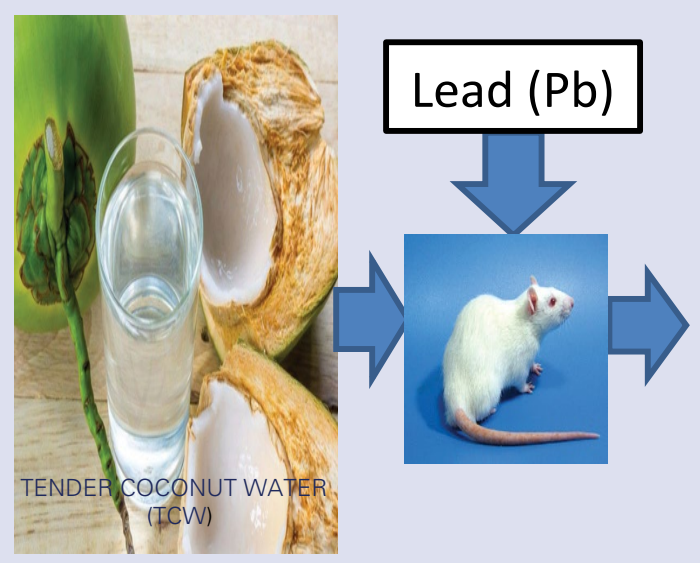

\begin{tabular}{llll}
\hline \multirow{2}{*}{ VARIABLE } & \multicolumn{3}{c}{ Group } \\
\cline { 2 - 4 } & \multicolumn{2}{c}{$\mathbf{1}$} & \multicolumn{1}{c}{$\mathbf{3}$} \\
\cline { 2 - 4 } & Means \pm SD & Means \pm SD & Means \pm SD \\
\hline Hemoglobin levels(g/dL) & & & \\
Shapiro wilk & $15,98 \pm 0,55$ & $8,2 \pm 0,16$ & $14,94 \pm 0,76$ \\
Levene test & 0,511 & 0,930 & 0,279 \\
One way Anova & & & \\
Hematocrit Levels(\%) & & & \\
Shapiro wilk & $47,5 \pm 1,76$ & $24,5 \pm 0,54$ & $44,83 \pm 2,31$ \\
Levene test & 0,111 & 0,004 & 0,093 \\
One way Anova & & & \\
ErythrocyteLevels $\left(\mathrm{x} 10^{6} / \mathrm{mm}^{3}\right)$ & & & \\
Shapiro wilk & $8,64 \pm 0,23$ & $6,27 \pm 0,11$ & $7,37 \pm 0,08$ \\
Levene test & 0,493 & 0,073 & 0,331 \\
One way Anova & & & \\
\hline
\end{tabular}

\section{SUMMARY}

- Tender coconut water significantly increased the level of haemoglobin

- Tender coconut water significantly increased the level of hematokrit.

- Tender coconut water significantly increased the level of erythrocyte.

- Tender coconut water has the effect of preventing anemia.

\section{ABOUT AUTHORS}

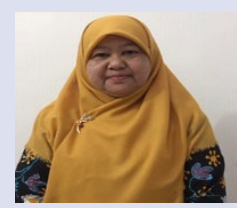

SitiThomas Zulaikhah: Is an Associate Profesor at the Departement of Public Health, Faculty of Medicine, Universitas Islam Sultan Agung Semarang-Indonesia. She is passionates in research on antioxidant especially Tender coconut water (TCW), prevention medicine and environment health.

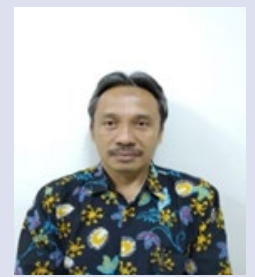

Joko Wahyu Wibowo: A lecture an researcher at Departement of Nutrion, Faculty of Medicine, Universitas Islam Sultan Agung Semarang-Indonesia. He is passionates in research on community nutrion and HIVAIDS. 


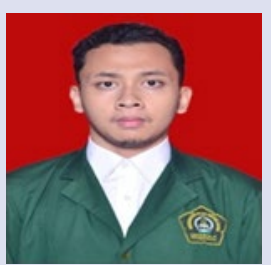

Aziz Rakha Dinarjo: Was a student at Universitas Islam Sultan Agung, Semarang-Indonesia, where he graduated in Bachelor of Medicine. His research focused on effect tender coconut water (TCW) on the erytrocyte level on Wistar Rats Induced by Lead (Plumbum).

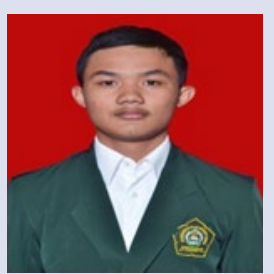

Dede Rizky Pramana: Was a student at Universitas Islam Sultan Agung, Semarang-Indonesia, where she graduated in Bachelor of Medicine. His research focused on the effect tender coconut water (TCW) on the hematocrit level on Wistar Rats Induced by Lead (Plumbum).

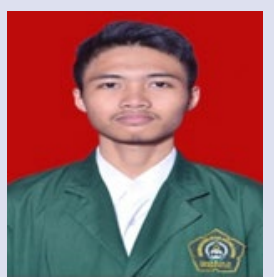

Ahmad Fauzi Noviantara: Was a student at Universitas Islam Sultan Agung, Semarang-Indonesia, where she graduated in Bachelor of Medicine. His research focused on the effect tender coconut water (TCW) on the hemoglobine level on Wistar Rats Induced by Lead (Plumbum)

Cite this article: Zulaikhah ST, Wahyuwibowo J, Rakha AD, Rizky DP, Fauzi AN. Effect of Tender Coconut Water to Prevent Anemia on Wistar Rats Induced by Lead (Plumbum). Pharmacog J. 2019;11 (6):1325-30. 